Article

\title{
Effect of Various Coolant Mass Flow Rates on Sealing Effectiveness of Turbine Blade Rim Seal at First Stage Gas Turbine Experimental Facility
}

\author{
Seok Min Choi ${ }^{1}$, Seungyeong Choi ${ }^{2}$ and Hyung Hee Cho ${ }^{2, *}$ \\ 1 Department of Plant Technology Energy Systems Research Division, Korea Institute of Machinery \& Materials, \\ Daejeon 34103, Korea; choism@kimm.re.kr \\ 2 Department of Mechanical Engineering, Yonsei University, Seoul 03722, Korea; haltjjak@yonsei.ac.kr \\ * Correspondence: hhcho@yonsei.ac.kr; Tel.: +82-2-2123-2828
}

Received: 10 July 2020; Accepted: 5 August 2020; Published: 7 August 2020

check for updates

\begin{abstract}
The appropriate coolant mass flow of turbine blade rim seal has become an important issue as turbine blades are exposed to increasingly higher thermal load owing to increased turbine inlet temperature. If the coolant is deficient, hot gas ingresses to the rim seal, or if sufficient, the efficiency of turbine decreases. Therefore, we analyzed sealing effectiveness of rim seal derive appropriate coolant mass flow rate at various conditions. The experimental facility was modified from one designed for an aero-engine gas turbine. Rotational Reynolds number varied from $3 \times 10^{5}$ to $5 \times 10^{5}$ based on rotational speed. Pressure was measured at various locations in the shroud, endwall, and rim seal. $\mathrm{CO}_{2}$ concentration was measured at various rim seal locations to analyze sealing effectiveness. Measured results showed that $1.35 \%$ coolant mass flow rate of rim seal exhibited a little ingress effect, whereas lower coolant mass flow rates exhibited higher ingress effect. A predicted correlation for sealing effectiveness of rim seal was derived at various rotational Reynolds number and coolant mass flow rate. The correlation will be useful for turbine cooling design, helping to predict sealing effectiveness of rim seals during preliminary design processes for new gas turbines.
\end{abstract}

Keywords: gas turbine; blade; rim seal; sealing effectiveness

\section{Introduction}

To increase gas turbine efficiency and power output, the temperature of the combustor chamber increase continuously. As a result, the thermal load of the gas turbine high-temperature parts (burner, vanes, and blades) increases, and cooling becomes important. Accordingly, many studies have been conducted on the internal cooling, film cooling, and jet cooling of gas turbine blades, endwall, and tip. Recently, many studies on the flow characteristics and sealing effectiveness of rim seals have been conducted.

Chupp, R.E. et al. [1] reviewed the effect of reducing the efficiency of the cycle as the main flow gas ingresses to the turbine disk. They summarized the effect of the sealing gap of the turbomachinery. Bohn, D. et al. [2,3] analyzed the effects of blade on the ingress of the main flow. They compared the pressure distribution between the endwall and the rim seal and configured that the sealing effectiveness decreased in the presence of the blade. Coren, D.D. et al. [4] constructed an experimental facility that can test the interactions between the rim seal cooling flow and the main flow under various operating conditions. They measured pressure and temperature distributions and used them as data for conjugate numerical simulations. Gentillhomme, O. et al. [5] measured the ingress effect through the measurement of carbon dioxide concentration in the rim seal. The results show that the velocity coefficient is an important variable for the analysis of ingress effect. Sangan, C.M. et al. [6] analyzed the 
ingress effect and derived correlations of sealing effectiveness of rim seal. Pau, M. et al. [7] measured the heat transfer coefficient and pressure distributions and confirmed that the heat transfer coefficient of the endwall was increased owing to the existence of the coolant of the rim seal. Bayley, F.J. and Owen, J.M. [8] found out the flow characteristics of the shrouded disk system. They focused on the radial outflow of the coolant and figured out the general characteristics of the radial flow. Owen, J.M. and Rogers, R.H. [9,10] figured out the flow and heat transfer of rotating disc in rotor-stator system and rotating cavity. Owen, J.M. [11,12] categorized the causes of ingress effect. Owen, J.M. et al. [13-15] theoretically modeled the ingress of the turbine rim seal. They modeled the ingress and egress effect and compared the experimental results with their predictions. Zhou, K. et al. [16] derived the statistical and theoretical model of the ingress of turbine rim seal. Isobel Mear, L. et al. [17] derived the theoretical model for ingress of turbine rim seal. Johnson, B.V. et al. [18] developed the "orifice model" that describes ingress and egress effects on the basis of pressure measurements. They continued to refine the orifice model based on additional experiments and interpretations. Therefore, many researchers and gas turbine cooling designers can use this model to predict the ingress effect at the preliminary design stage. Zhang, Z., and Ma, H., [19] conducted phase locked particle image velocimetry (PIV) method to figure out the flow characteristics of turbine rim seal.

Many researchers also conducted computational analysis to further analyze the flow characteristics of rim seal of turbine blade. Cao, C. [20], Hills, N.J. [21], Teuber, R., [22], and Ding, Z. [23] conducted unsteady state numerical simulations on the interaction between main flow and coolant of rim seal. They confirmed that the unsteady state numerical analysis predicts the flow more accurately than the steady state numerical analysis. This unsteady state computational analysis helped in-depth understanding of flow characteristics that are difficult to presume in detail by experiments. Tucker, P.G. et al. [24] compared the Large Eddy Simulation (LES) and hybrid LES analysis. They found that although the LES analysis is costly and time consuming, the LES analysis is more accurate in the analysis of unsteady state flows in turbomachinery. Chilla, M. et al. [25] confirmed that the eddy shedding caused by blade rotation caused the total pressure of the turbine to be unstable by numerical simulations. Rabs, M. et al. [26] confirmed that the Kelvin Helmholtz instability increased with increasing mass flow rate of the rim seal. $\mathrm{Wu}, \mathrm{H}$. et al. [27] conducted numerical simulations by using 1D-3D structure couple method to predict the unsteady flow condition of the secondary cooling system. $\mathrm{Du}, \mathrm{M}$. et al. $[28,29]$ conducted numerical simulations to find out the flow characteristics of near hub affected by secondary flow of rim seal.

Through a number of studies, the causes of the ingress effect were analyzed as follows.

1. Pressure difference by the shape of gas turbine vane.

2. Gas turbine blade rotation.

3. Gas turbine off-design operation.

Owing to the above factors, the main flow ingress effect is caused. However, the blade damages can be caused by the non-uniform heat load on the rim seal of turbine blade. In order to suppress the ingress effect and to improve the sealing effectiveness, the shape development of the rim seal was conducted. Sangan, C.M. et al. [30] compared the ingress effect of a single rim seal and a double rim seal. They found that the double rim seal showed higher sealing effectiveness and the radially outer rim seal dominated the sealing effectiveness. Zhou. D.W. et al. [31] compared three different shapes of rim seal and confirmed that the ingress effect decreased as the aspect ratio of the rim seal cavity decreased. Bohn, D. et al. [2,3] developed an improved rim seal configuration for minimal cooling flow. They found that the double rim seals had higher sealing effectiveness than other rim seal configurations. Schuler, P. et al. [32] compared the aerodynamic losses of various rim seal configurations through numerical simulations. They found that the compound rim seal configuration showed reduced ingress effect. Scobie, J.A. et al. [33] found an angel-wing rim seal configuration that showed improved sealing effectiveness compared to double rim seal configurations. Barringer, M. et al. [34] designed an experimental facility which can be operated near the operating conditions of aero gas turbine. 
They plan to find the optimal cooling flow for rim seals and to derive the optimal shapes of rim seals in the future.

In addition, other researchers have investigated the ingress effect owing to changes of operating conditions and coolant mass flow rate of gas turbines. Green, T. and Turner, A.B. [35] confirmed that the ingress effect increased with increasing blade rotation speed. Roy, R.P. et al. [36] conducted experiments based on the main flow, cooling flow, and rotational speed and derived dimensionless variable to predict the sealing effectiveness of the rim seals. Eastwood, D. et al. [37] found that increasing the cooling flow rate of the rim seal reduced the ingress effect. Regina, K. et al. [38] confirmed that the sealing effectiveness of the rim seal decreases as incidence angle of blade changes during off-design conditions. Wang, R. et al. [39] analyzed the influence of secondary flow of the rim seal on the axial turbine. They found out that mass flow rate of rim seal and flow rate ratio of main flow and secondary flow is important factor for sealing efficiency. Balasubramanian, J. et al. [40] constructed the experimental facility with single rim seal. They found out the sealing effectiveness of rim seal in different operating conditions.

A number of studies have been conducted to analyze the sealing effectiveness of rim seal of gas turbine blade. However, establishing a test facility to measure the sealing effectiveness of the rim seals is expensive and difficult to manufacture, which does not have accumulated data compared to other cooling technologies (internal cooling, membrane cooling, jet cooling, etc.). In addition, the amount of cooling flow generally applied to the gas turbine blade rim seal is known to be $1-2 \%$ of the main flow. However, when more cooling flow is used, gas turbine efficiency decreased, and when less flow is used, vanes and blades can be damaged owing to ingress effect. Therefore, appropriate cooling flow of rim seals should be considered, especially at the preliminary design status of the gas turbine. In this study, we designed and constructed an experimental facility to measure the sealing effectiveness of gas turbine blade rim seal. The flow pattern in the rim seal changes according to the gap of the rim seal and rotational Reynolds number as shown in Figure 1. When the gap of rim seal and rotational Reynolds number are small (Regime I), flow near stator and rotor egresses the rim seal by forming the laminar flow. However, if the gap is larger (Regime II), the flow near rotor egresses the rim seal. On the other hand, the flow near stator ingresses the rim seal as counter to flow near stator. Furthermore, when the gap of rim seal is small and rotational Reynolds number is large (Regime III), flow near stator and rotor egresses the rim seal by forming the turbulent flow. However, if the gap is large (Regime IV), the flow near rotor egresses the rim seal whereas near rotor forming counter flow. Generally, the operating condition of the aero-gas turbine is over one million of rotational Reynolds number. Thus, the flow of rim seal of aero-gas turbine is operated at flow regime IV. Therefore, the experimental conditions were shown in Figure 1, and the specific experimental conditions are explained in detail in the "3. Results and Discussion" Section 3. The experiments were carried out on the various blade rotational speed and cooling flow rates of rim seal. The cooling flow rates of the rim seal is about $0.5-1.35 \%$ of the main flow, and based on this, a correlation for predicting the sealing effectiveness of the rim seal is derived. The experimental results of this study can be used as basic data for gas turbine blade rim seal design. When designing a new gas turbine, the gas turbine designers can use this correlation for predicting the sealing effectiveness of rim seal in preliminary design process. Therefore, the data and correlation of this paper will be helpful for the gas turbine industry. 


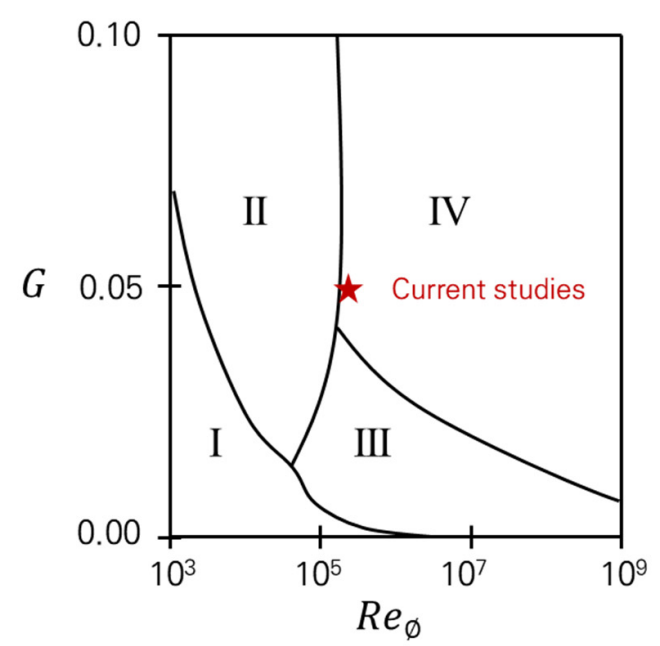

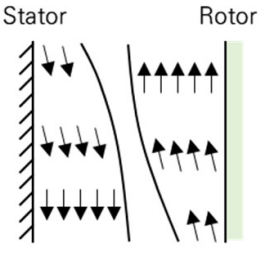

Regime II Flow

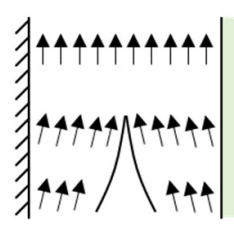

Regime I Flow

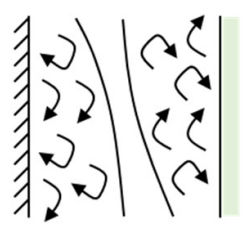

Regime IV Flow

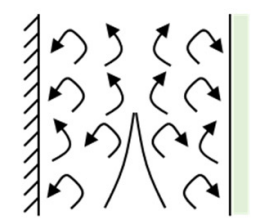

Regime III Flow

Figure 1. Rim seal experimental conditions and flow regimes [41].

\section{Experiment Method}

\subsection{Experimental Facility}

Figure 2 showed a schematic of experimental facility which was equipped with vanes, blades, and de-swirlers. The de-swirlers were installed to reduce the pressure loss. The $25.3 \mathrm{~kW}$ turbofan blower has a total discharge pressure of $816 \mathrm{mmAq}$ and a $200 \mathrm{mmAq}$ blower for secondary flow to the rim seal. In the middle, an electric motor was installed to maintain a constant rotational speed of the gas turbine blades. Pressure taps were installed to measure the local pressure distributions of the shroud, endwall and rim seals, and panels were made to facilitate the measurement of each measurement position. The pressure at the local locations were measured by pressure scanner, which was connected to a computer to obtain data. During the experiment, carbon dioxide was injected to the flow of the rim seal. The concentration of carbon dioxide was $4 \%$ of the flow. To measure the sealing effectiveness of rim seal, a gas sampling system was made. A vacuum pump was used to drain the gas from the measurement points. An ND-IR gas analyzer was used to analyze the concentration of carbon dioxide in the captured gas. Details of this step is described in detail in the "2.3. Carbon dioxide concentration measurement method" Section 2.3. The inlet velocity was measured by a L-type pitot tube $(6 \mathrm{~mm}$ head diameter, KIMO Instruments) which was installed at the front end of the nozzle. The uncertainty of the pitot tube has an error of $1 \%$ within $10^{\circ}$. The flow rate of the main flow was varied from 0.41 to $0.69 \mathrm{~kg} / \mathrm{s}$, which was carried out in the range of $1.4 \times 10^{4}$ to $2.3 \times 10^{4}$ Reynolds number based on the vane chord length and inlet velocity. Blade rotational speed was measured by a stroboscope (Nova-Pro 300S, Monarch Instrument, Amherst, USA). The rotational speed was measured using a transmission window installed on the shroud between the vane and the blade. The stroboscope has an error rate of $1 \mathrm{rpm}$ in the range of 30-500,000 rpm.

Figure $2 \mathrm{~b}$ showed the configurations of gas turbine vane, blade, and rim seal. The diameter of the rotor was $267 \mathrm{~mm}$. The gap between the vane and blade was $12 \mathrm{~mm}$. The axial chord length of the vane was $30 \mathrm{~mm}$. The profiles of gas turbine vane and blade of Figure $2 \mathrm{~b}$ were based on the profile of the mid-section of the aero-gas turbine vane and blade. The size of vanes and blades are 1.5 times larger than actual aero-gas turbine vane and blade. The blade height was manufactured as $50 \%$ of actual size to reduce the mass flow rate of main flow used in the experiment. Detailed parameters of vanes and blades were shown in Table 1. In addition, the shape of the rim seal showed that the total gap between the vanes and the blade was $G_{h / b}=0.046$ and the overlapping gap was $G_{\text {overlab } / b}=0.008$. The thickness of the vane and blade rim seals was $S_{v, 1 / b}=0.019$ and $S_{v, 1 / b}=0.011$, respectively. The gap of the rim seal in the vertical direction was $G_{v, 1 / b}=0.015$, and the gap in the horizontal direction was $G_{h, 1 / b}=0.016, G_{h, 2 / b}=0.022$, and $G_{h, 3 / b}=0.016$, respectively. 
(a)
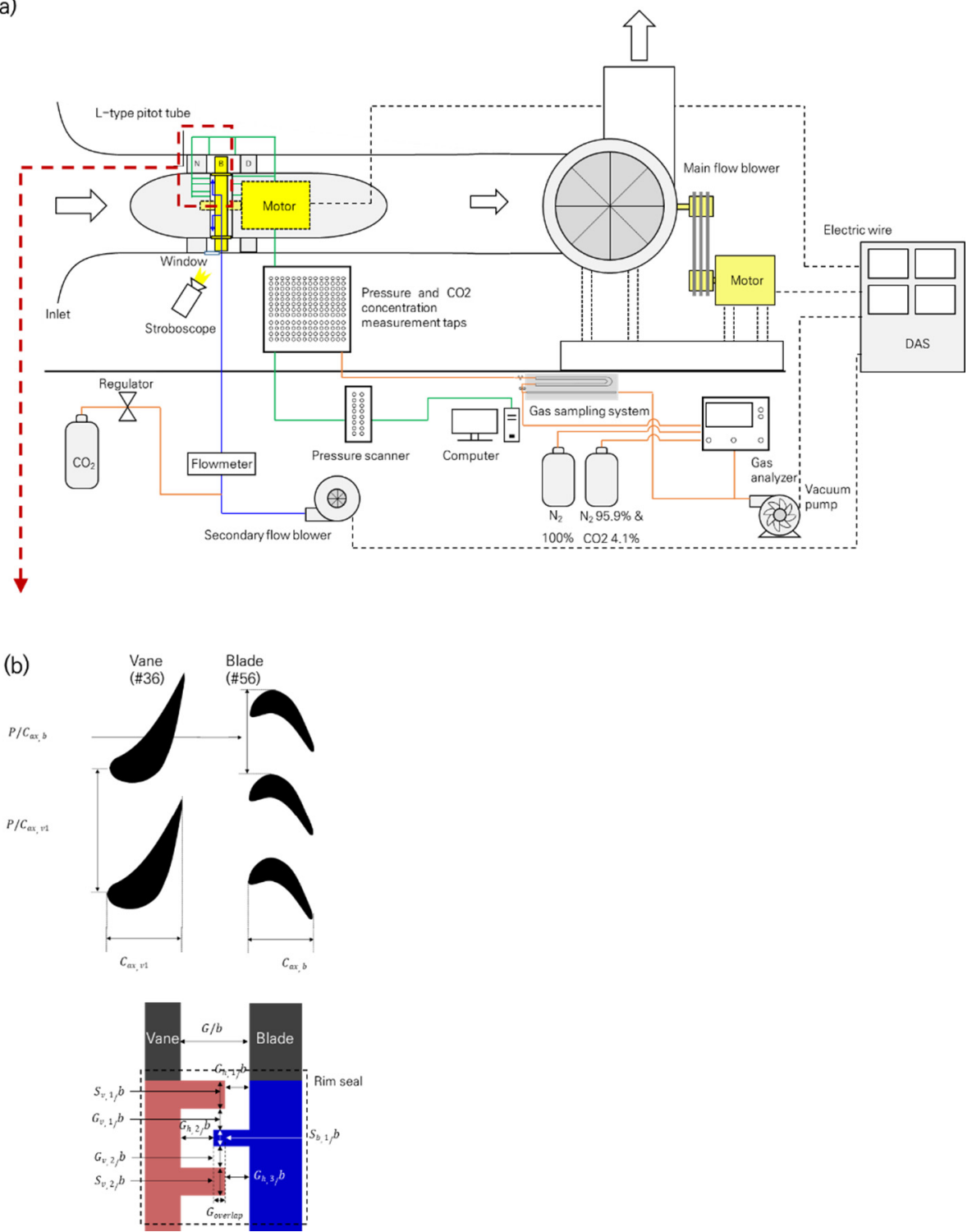

Figure 2. (a) Schematic of experimental facility; (b) Turbine vane, blade profile and rim seal configuration.

Table 1. Turbine vane and blade parameters.

\begin{tabular}{ccc}
\hline Parameter & Vane & Blade \\
\hline No. of airfoil & 36 & 56 \\
Axial chord length ratio $\left(\mathrm{C}_{\mathrm{ax}, \mathrm{i}} / \mathrm{C}_{\mathrm{ax}, \mathrm{v} 1}\right)$ & 1 & 0.877 \\
Pitch of blade $\left(\mathrm{P} / \mathrm{C}_{\mathrm{ax}, \mathrm{i}}\right)$ & 1.09 & 0.8 \\
Span of blade $\left(\mathrm{S} / \mathrm{C}_{\mathrm{ax}, \mathrm{i}}\right)$ & 0.77 & 0.8 \\
Blade inlet angle & $0^{\circ}$ & $54.4^{\circ}$ \\
Blade outlet angle & $77^{\circ}$ & $-67^{\circ}$ \\
Turning angle & $77^{\circ}$ & $121.7^{\circ}$ \\
\hline
\end{tabular}

\subsection{Pressure Measurement Method}

Figure 3 showed the pressure measurement locations installed to measure the sealing effectiveness of the rim seals. Figure 3a showed 14 measurement locations manufactured on each shroud and endwall. Every pressure tap had a diameter of $0.8 \mathrm{~mm}$ and were located $32 \mathrm{~mm}$ after the trailing edge of vane. Figure $3 b$ showed the local measurement locations of rim seal. The ingress effect of rim seal 
can be confirmed by comparing the pressure measurements data. Fourteen measurements taps were made in the circumferential direction at $r / R=0.89$ and 0.855 and seven measurement taps were made in the circumferential direction at $r / R=0.83$. In order to regard as reference point, two measurement taps were made at $r / R=0.81$ and $r / R=0.743$. Pressure measurements were conducted using the PSI9116 device (Pressure system Inc. Phoenix, USA) to measure the 16 points simultaneously. The device has an error of $0.15 \%$ in the range of $\pm 5 \mathrm{kPa}$. So, the detection range of pressure measurements was from $-5 \mathrm{kPa}$ to $5 \mathrm{kPa}$. The pressure measurement was conducted for $1 \mathrm{~min}$ at $2 \mathrm{~Hz}$. The measured data were stored in a computer, and the values presented in this experiments are averaged values.

(a)

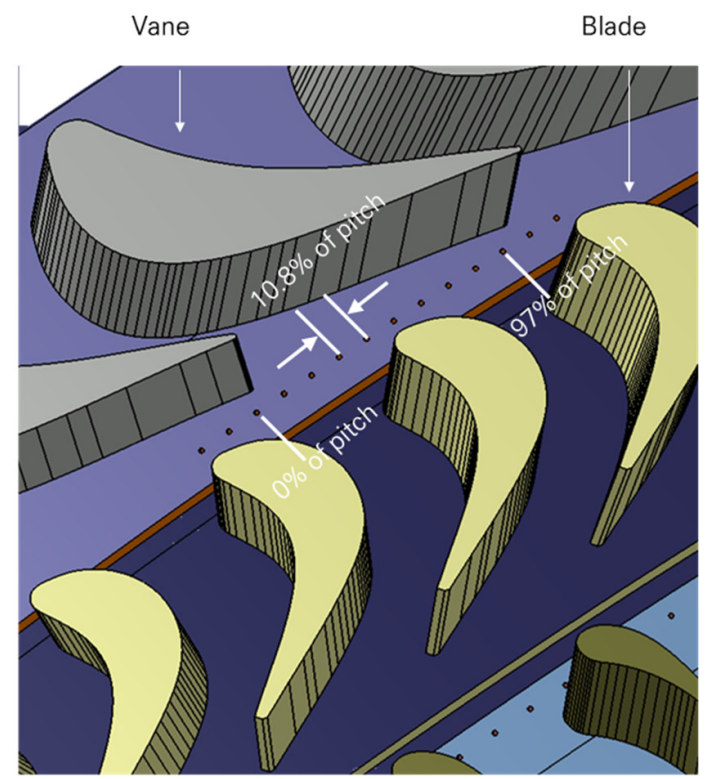

(b)

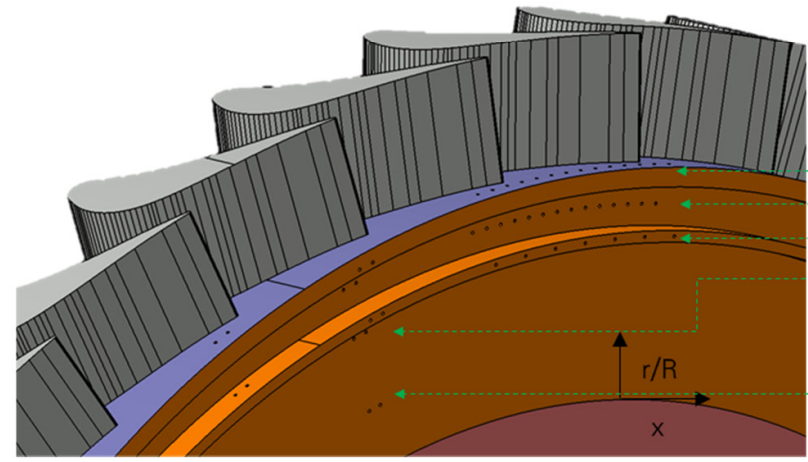

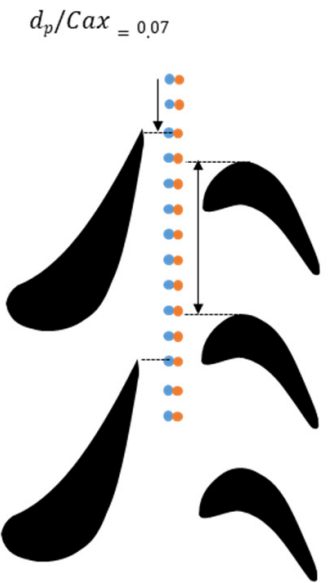

Vane endwall

Vane shroud

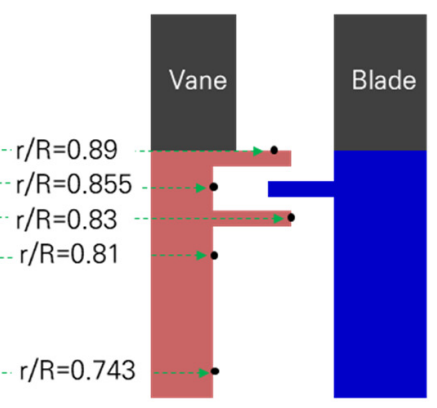

Figure 3. (a) Pressure measurement tap locations on turbine endwall and shroud, and (b) pressure and $\mathrm{CO}_{2}$ measurement tap locations on rim seal.

\subsection{Carbon Dioxide Concentration Measurement Method}

Carbon dioxide concentration was measured in the same locations of the pressure measurement taps. Figure 4 showed a gas sampling system. This system was made with reference to the experimental method of Pedersen, D.R. [42]. Thirty circular cylinders for capturing carbon dioxide are installed side by side in the wood case. The diameter of cylinder was $10 \mathrm{~mm}$ and length was $700 \mathrm{~mm}$. The tip of each cylinder inlet was sealed with a rubber stopper to prevent leakage. A rubber stopper has $2 \mathrm{~mm}$ diameter hole at the center to collect air from the experimental facility. The $2 \mathrm{~mm}$ diameter of glass tube was installed at the rubber stopper. One end of the circular cylinder was connected to the experimental equipment, and each measuring positions for sampling gas were the same as the pressure measurement taps. The tygon tube connected the glass tube and the measurement taps. The other end of the circular cylinder was connected to a vacuum pump with a manifold in between. The flow 
resistance was increased by connecting a capillary tube with a diameter of $0.7 \mathrm{~mm}$ between the cylinder and the manifold. This was to prevent fluid from escaping rapidly during gas sampling in the cylinder. A tap valve was installed between the manifold and the vacuum pump to regulate the drain rate of the vacuum pump. The used vacuum pump was MVP-24 (Woosung Vacuum Co. Ltd., Jeju, South Korea) and has a maximum flow rate of $400 \mathrm{~L} / \mathrm{min}$. When the gas was fully collected, plug the clamps at the front and back of the cylinder to hold the air in the cylinder. The collected air was connected to a carbon dioxide concentration measuring device. A ZRU gas analyzer (Fuji Electric Co., Tokyo, Japan) was used. The suction rate of device was $\pm 0.2 \mathrm{~L} / \mathrm{min}$. Before analyzing the data, the carbon dioxide measuring device should be calibrated. The reference point was set by $100 \%$ nitrogen gas, and the gas analysis sheet of the measuring device was calibrated using a gas mixed with $4.1 \%$ carbon dioxide and 95.9\% nitrogen. Each circular cylinder was then connected to a gas analyzer to analyze the carbon dioxide concentration at each location. The error of the gas analyzer was within $0.025 \%$.

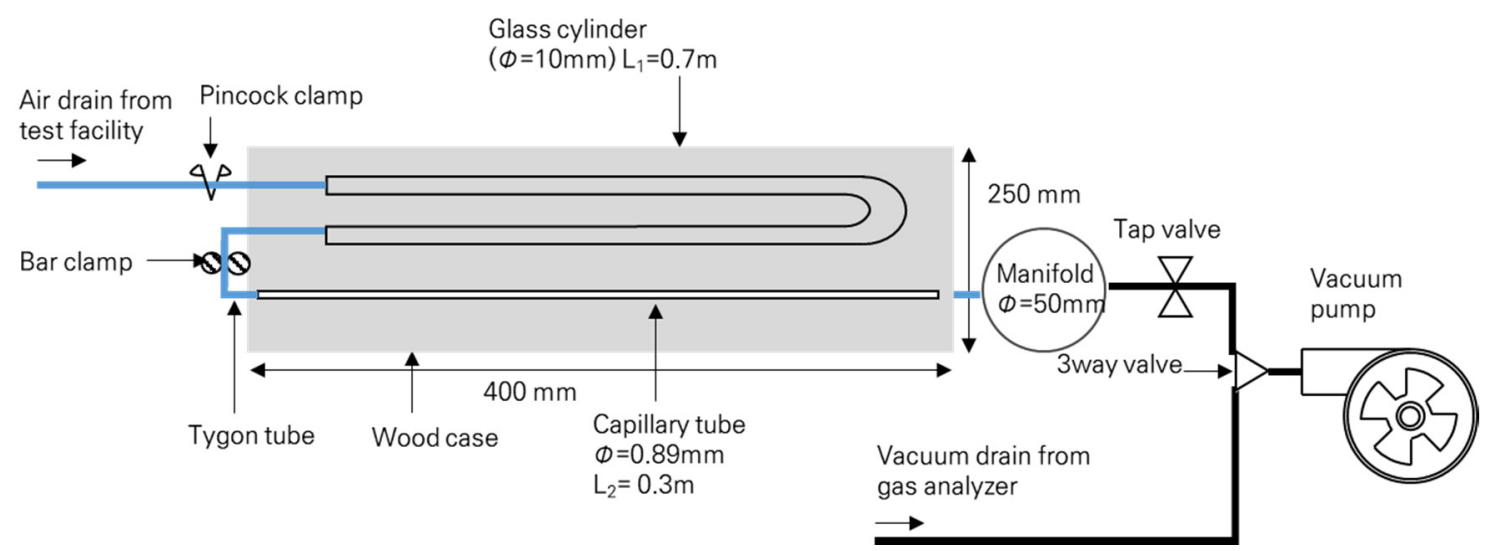

Figure 4. Gas sampling system.

\subsection{Experimental Parameters and Non-Dimensional Number Definitions}

The key parameters in this experiment are rotational Reynolds number and the coolant mass flow rate of the rim seal. The rotating Reynolds number and the coolant mass flow rate are defined as follows.

$$
R e_{\phi}=\frac{\rho \Omega b^{2}}{\mu}
$$

where $\rho$ is the air density, $\Omega$ is rotational speed, $b$ is hub radius, and $\mu$ is air dynamic viscosity; and nondimensional secondary flow as

$$
C_{w}=\frac{\dot{m}}{\mu b}
$$

where $C_{w}$ is secondary flow from rim seal of vane and blade.

The pressure coefficient, $C_{p}$, can be calculated from the measured pressures,

$$
C_{p}=\frac{p_{i, s}-p_{\infty}}{0.5 \rho \Omega^{2} b^{2}}
$$

where $p_{i, s}$ is local static pressure, $p_{\infty}$ is ambient air pressure; and sealing effectiveness, $\eta$, can be expressed as

$$
\eta=\frac{c_{i}-c_{a}}{c_{0}-c_{a}} \approx \frac{c_{i}}{c_{0}}
$$

where $c_{0}, c_{a}$, and $c_{i}$ are $\mathrm{CO}_{2}$ concentration at the bottom of rim seal $(r / R=0.736)$, ambient air, and local concentration in air, respectively. We can assume $c_{a} \approx 0$, because the mixture $\mathrm{CO}_{2}$ concentration is high enough to neglect ambient air concentration. 


\subsection{Uncertainty Analysis}

The uncertainty of the rotational Reynolds number was calculating by the uncertainty estimation method by Abernety [43],

$$
\frac{\Delta \operatorname{Re}_{\phi}}{\operatorname{Re}_{\phi}}=\left[\left(\frac{\Delta \rho}{\rho}\right)^{2}+\left(\frac{\Delta \mu}{\mu}\right)^{2}+\left(\frac{\Delta \Omega}{\Omega}\right)^{2}+\left(\frac{\Delta \mathrm{b}}{\mathrm{b}}\right)^{2}\right]^{1 / 2}
$$

where the uncertainty of the air density and viscosity were nearly zero. The uncertainty of the rotational speed was $2.0-3.3 \%$ for different rotating speed. The manufacturing uncertainty of the hub was $0.4 \%$. Therefore, the uncertainty of the rotational Reynolds number was $2.1-3.3 \%$. The uncertainty of the nondimensional secondary flow was shown below,

$$
\frac{\Delta C_{w}}{C_{w}}=\left[\left(\frac{\Delta \dot{m}}{\dot{m}}\right)^{2}+\left(\frac{\Delta \mu}{\mu}\right)^{2}+\left(\frac{\Delta b}{b}\right)^{2}\right]^{1 / 2}
$$

where the uncertainty of the mass flow rate was $2 \%$. Therefore, the uncertainty of the nondimensional secondary flow was $2.1 \%$. The uncertainty of the pressure coefficient was shown as below,

$$
\frac{\Delta C_{p}}{C_{p}}=\left[\left(\frac{\Delta p_{i, s}}{p_{i}}\right)^{2}+\left(\frac{\Delta \mu}{\mu}\right)^{2}+\left(\frac{\Delta \Omega}{\Omega}\right)^{2}+\left(\frac{\Delta b}{b}\right)^{2}\right]^{1 / 2}
$$

where the uncertainty of the local pressure measurement was $0.8 \%$. Therefore, the uncertainty of the pressure coefficient was $2.1-3.4 \%$. The uncertainty of the sealing effectiveness was shown as below,

$$
\frac{\Delta \eta}{\eta}=\left[\left(\frac{\Delta c_{0}}{c_{0}}\right)^{2}+\left(\frac{\Delta c_{i}}{c_{i}}\right)^{2}+\left(\frac{\Delta c_{a}}{c_{a}}\right)^{2}\right]^{1 / 2}
$$

where the uncertainty of the concentration of bottom rim seal and local concentration was $0.63 \%$. The uncertainty of the concentration of ambient air was nearly zero. Therefore, the uncertainty of sealing effectiveness was $0.9 \%$.

\section{Results and Discussion}

Figure 5 showed the results of local pressure and sealing effectiveness distributions in two cases where the cooling flow rate of the rim seal is different. Local pressure measurement distributions on the shroud and endwall showed high pressure distributions near the vane trailing edge. On the other hand, lower pressure distributions are shown in the passage region of the main flow. This is because the vane accelerates the main flow resulting in higher velocity. This tendency was not significantly different even if the cooling flow rate of the rim seal changed comparing with Figure $5 a, b$. However, the pressure distributions changed according to the coolant mass flow rate of the rim seal. Figure $5 \mathrm{a}$ showed that when the $1.35 \%$ of the main flow coolant was injected, the pressure distributions of $r / R=0.855$ showed higher values than that of the endwall in all regions. Therefore, it can be seen that the coolant of the rim seal flow egresses well into the main flow. On the other hand, Figure $5 \mathrm{~b}$ showed that the pressure distributions of the endwall was higher than that of the rim seal in the $0-20 \%$ of pitch. In other words, the coolant of the rim seal egresses well into the corresponding area, and the ingress effect of the main flow might occur. Figure $5 c$,d showed local sealing effectiveness distributions of rim seal. The $r / R=0.736$ and 803 of rim seal showed $100 \%$ sealing effectiveness, respectively. Near the disk hub of the rim seal, the main flow did not ingress, resulting in 100\% sealing effectiveness. However, the local sealing effectiveness was shown differently at $r / R=0.825$ and 0.855 region, respectively. Figure $5 \mathrm{c}$ showed that the local sealing effectiveness was $90-100 \%$ in most areas. In contrast, Figure $5 \mathrm{~d}$ showed $90-100 \%$ sealing effectiveness at $r / R=0.825$, but large variations of sealing effectiveness were 
shown at $r / R=0.855$ region. In particular, $0-20 \%$ pitch where the main flow ingress effect was expected, showed $50 \%$ of sealing effectiveness. In other words, when seeing the above results, it is necessary to inject the appropriate amount of coolant flow to prevent the main flow ingress effect into rim seal.

The local pressure measurements result when the coolant mass flow rate of the rim seal varied are shown in Figure 6. Figure 6 showed the pressure distributions result when the coolant of the rim seal varied from 0.5 to $1.35 \%$ of the main flow. The result showed that the local pressure distributions of rim seal decreases as the coolant mass flow rate of the rim seal decreases. In particular, it can be seen that the pressure distributions of the endwall near the trailing edge of the vane ( $10 \%$ of pitch) was larger than that of the rim seal, so that the ingress effect might occur. This phenomenon similarly occurred from Figure $6 \mathrm{~b}$ to Figure $6 \mathrm{f}$. In addition, it can be seen that as the coolant mass flow rate decreased, an area where the pressure distribution of the endwall was larger than that of the rim seal gradually increased. Since the amount of coolant flow decreased, it can be seen that the size of the area where the ingress effect occurred gradually increased. Similarly, as the coolant mass flow rate decreased, the pressure distributions of the rim seal gradually decreased, so that the area where the pressure distribution of the rim seal $(r / R=0.855)$ was larger than that of the endwall was reduced. Figure $6 \mathrm{c}$ showed that the pressure distributions of the rim seal were larger than that of the endwall at $17.5-100 \%$ pitch when $1.13 \%$ of the main flow coolant injected. On the other hand, Figure 6e showed that the pressure distribution of the rim seal was larger than that of the endwall at $21-96 \%$ pitch when $0.5 \%$ of the main flow coolant injected. That is, when the coolant flow was reduced, it can be seen that the area where the egress effect occurred gradually decreases.

In order to generalize these effects, additional experiments were conducted under conditions of $4.2 \times 10^{5}$ and $3.15 \times 10^{5}$, respectively, for rotational Reynolds number, and the experimental conditions are shown in Table 2. Generally, the rotational Reynolds number of aero-gas turbine is over one million and coolant mass flow rates were within $1-2 \%$ of actual aero engine. Thus, the ratio of coolant mass flow rate and rotational Reynolds number is $0.007<C_{w} / R e_{\phi}<0.013$. So, we chose the experimental conditions as shown in Table 2. In all experimental cases, the flow coefficient $(\varphi)$ was maintained at 0.34. The pressure measurement results of case 2-1 to 2-6 and case 3-1 to 3-6 were shown to be similar to Figure 6 (case 1-1 to 1-6). Therefore, the experimental results showed that even if rotational Reynolds number is different, proportional to the amount of coolant flow of the rim seal of showed ingress effect of the main flow.

(a)

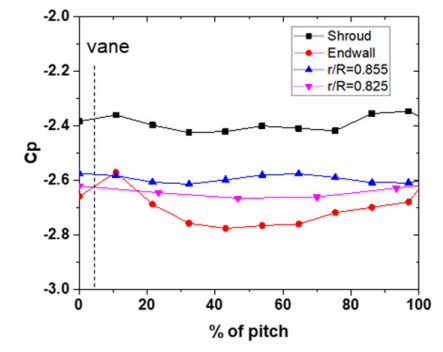

(c)

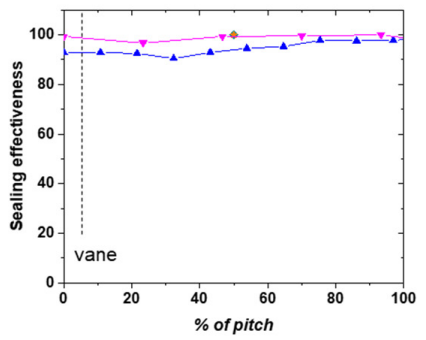

(b)

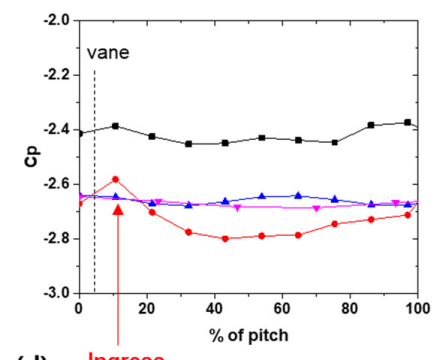

(d)

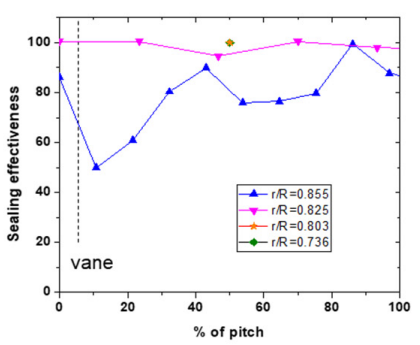

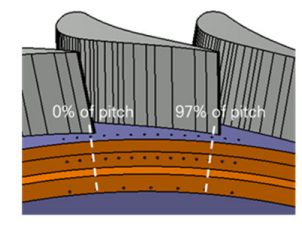

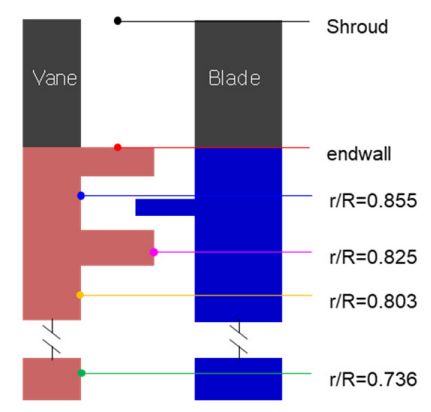

Figure 5. Local pressure distributions: (a) 1.35\% and (b) 1\% actual engine air flow; local seal effectiveness: (c) $1.35 \%$ and (d) $1 \%$ actual engine air flow at $\operatorname{Re}_{\phi} \cong 5.2 \times 10^{5}$. 
(a)

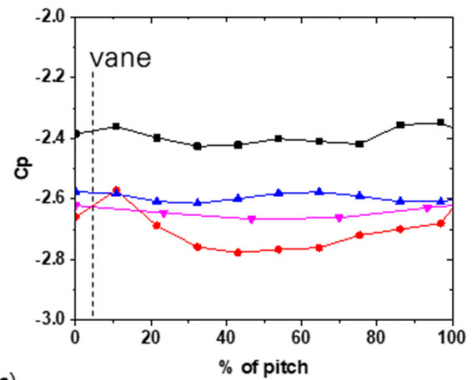

(c)

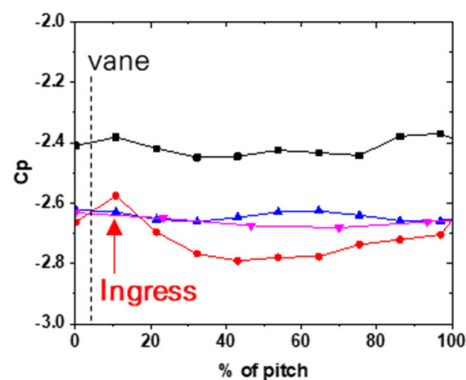

(e)

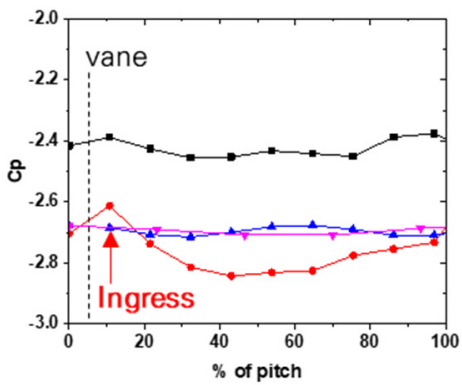

(b)

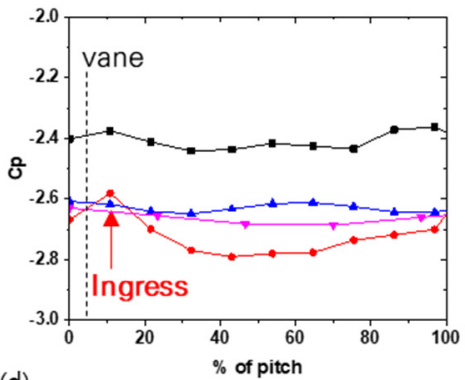

(d)

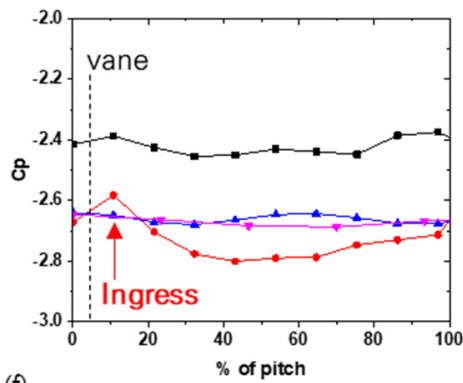

(f)

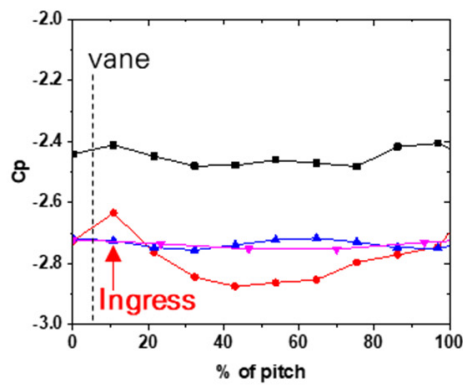

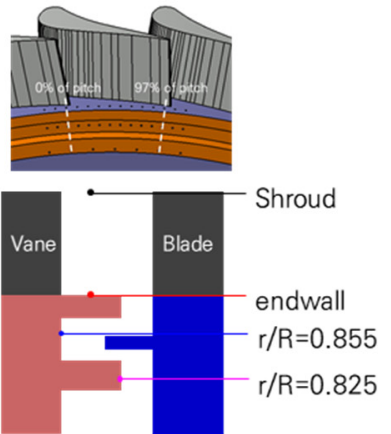

$r / R=0.825$

Figure 6. Local pressure distributions: (a) $1.35 \%$, (b) $1.25 \%$, (c) $1.13 \%$, (d) $1 \%$, (e) $0.75 \%$, and (f) $0.5 \%$ actual engine air flow at $\operatorname{Re}_{\phi} \cong 5.2 \times 10^{5}$.

Table 2. Experimental conditions considered in the present study.

\begin{tabular}{|c|c|c|c|c|c|c|c|c|c|}
\hline \multirow{2}{*}{$\begin{array}{l}\text { Expt Set } \\
\text { Parameter }\end{array}$} & \multicolumn{2}{|c|}{ Rotor Speed } & \multicolumn{2}{|c|}{ Main Air Flow Rate } & \multicolumn{5}{|c|}{ Secondary Air } \\
\hline & rpm & $\operatorname{Re}_{\phi}$ & $\mathrm{kg} / \mathrm{s}$ & $\operatorname{Re}_{a x}$ & $\mathrm{~kg} / \mathrm{s}$ & $\mathrm{C}_{\mathrm{w}}$ & $\begin{array}{l}\text { \% of Main } \\
\text { Air Flow }\end{array}$ & $\begin{array}{c}\% \text { of Actual } \\
\text { Engine Air Flow }\end{array}$ & $\mathrm{V} / \mathrm{U}$ \\
\hline Case 1-1 & 1000 & $5.2 \times 10^{5}$ & 0.69 & $2.3 \times 10^{4}$ & 0.0371 & $7.0 \times 10^{3}$ & 5.4 & 1.35 & 0.34 \\
\hline Case 1-2 & 1000 & $5.2 \times 10^{5}$ & 0.69 & $2.3 \times 10^{4}$ & 0.0350 & $6.6 \times 10^{3}$ & 5.0 & 1.25 & 0.34 \\
\hline Case 1-3 & 1000 & $5.2 \times 10^{5}$ & 0.69 & $2.3 \times 10^{4}$ & 0.0311 & $5.9 \times 10^{3}$ & 4.5 & 1.13 & 0.34 \\
\hline Case 1-4 & 1000 & $5.2 \times 10^{5}$ & 0.69 & $2.3 \times 10^{4}$ & 0.0276 & $5.2 \times 10^{3}$ & 4.0 & 1 & 0.34 \\
\hline Case 1-5 & 1000 & $5.2 \times 10^{5}$ & 0.69 & $2.3 \times 10^{4}$ & 0.0207 & $3.9 \times 10^{3}$ & 3.0 & 0.75 & 0.34 \\
\hline Case 1-6 & 1000 & $5.2 \times 10^{5}$ & 0.69 & $2.3 \times 10^{4}$ & 0.01138 & $2.6 \times 10^{3}$ & 2.0 & 0.5 & 0.34 \\
\hline Case 2-1 & 800 & $4.2 \times 10^{5}$ & 0.55 & $1.8 \times 10^{4}$ & 0.0330 & $6.2 \times 10^{3}$ & 6.0 & 1.5 & 0.34 \\
\hline Case 2-2 & 800 & $4.2 \times 10^{5}$ & 0.55 & $1.8 \times 10^{4}$ & 0.0297 & $5.6 \times 10^{3}$ & 5.4 & 1.35 & 0.34 \\
\hline Case 2-3 & 800 & $4.2 \times 10^{5}$ & 0.55 & $1.8 \times 10^{4}$ & 0.0275 & $5.2 \times 10^{3}$ & 5.0 & 1.25 & 0.34 \\
\hline Case 2-4 & 800 & $4.2 \times 10^{5}$ & 0.55 & $1.8 \times 10^{4}$ & 0.0248 & $4.7 \times 10^{3}$ & 4.5 & 1.13 & 0.34 \\
\hline Case 2-5 & 800 & $4.2 \times 10^{5}$ & 0.55 & $1.8 \times 10^{4}$ & 0.0220 & $4.1 \times 10^{3}$ & 4.0 & 1 & 0.34 \\
\hline Case 2-6 & 800 & $4.2 \times 10^{5}$ & 0.55 & $1.8 \times 10^{4}$ & 0.0165 & $3.1 \times 10^{3}$ & 3.0 & 0.75 & 0.34 \\
\hline Case 3-1 & 600 & $3.1 \times 10^{5}$ & 0.41 & $1.4 \times 10^{4}$ & 0.0247 & $4.7 \times 10^{3}$ & 6.0 & 1.5 & 0.34 \\
\hline Case 3-2 & 600 & $3.1 \times 10^{5}$ & 0.41 & $1.4 \times 10^{4}$ & 0.0222 & $4.2 \times 10^{3}$ & 5.4 & 1.35 & 0.34 \\
\hline Case 3-3 & 600 & $3.1 \times 10^{5}$ & 0.41 & $1.4 \times 10^{4}$ & 0.0207 & $3.9 \times 10^{3}$ & 5.0 & 1.25 & 0.34 \\
\hline Case 3-4 & 600 & $3.1 \times 10^{5}$ & 0.41 & $1.4 \times 10^{4}$ & 0.0186 & $3.5 \times 10^{3}$ & 4.5 & 1.13 & 0.34 \\
\hline Case 3-5 & 600 & $3.1 \times 10^{5}$ & 0.41 & $1.4 \times 10^{4}$ & 0.0166 & $3.1 \times 10^{3}$ & 4.0 & 1 & 0.34 \\
\hline Case 3-6 & 600 & $3.1 \times 10^{5}$ & 0.41 & $1.4 \times 10^{4}$ & 0.0124 & $2.3 \times 10^{3}$ & 3.0 & 0.75 & 0.34 \\
\hline
\end{tabular}

Based on those experimental results the area where the ingress effect might be occurred was calculated. The local pressure difference of $r / R=0.855$ of rim seal and endwall was shown in Figure $7 \mathrm{a}$. The results showed that the different rotational Reynolds numbers showed different pressure 
measurement difference between rim seal and endwall; however, the regime where the ingress and egress effects were occurred was similarly shown. So, we can conclude that near the trailing edge of the vane showed the ingress effects when the operating conditions were varied. As a result of calculation, an area larger than zero is assumed where the ingress effect of the main flow might have occurred, and an area smaller than zero is assumed where the egress effect of the main flow might have occurred. Therefore, the area ratio of egress effect to the total area was calculated for every experimental condition as shown in Figure 7b. It can be seen that the egress effect increased as the coolant mass flow rate increased. Especially, when the coolant mass flow rate was $1.13-1.35 \%$ of the main flow, more than $95 \%$ of the total coolant flow seems to be effectively used for sealing of the rim seal, and when that was $0.5-0.75 \%$ of the main flow, $90 \%$ or less of coolant flow was effectively used for sealing of the rim seal. Therefore, in order to effectively cool the gas turbine blade rim seal, it can be seen that the $1 \%$ or more of the main flow of coolant was required.

(a)

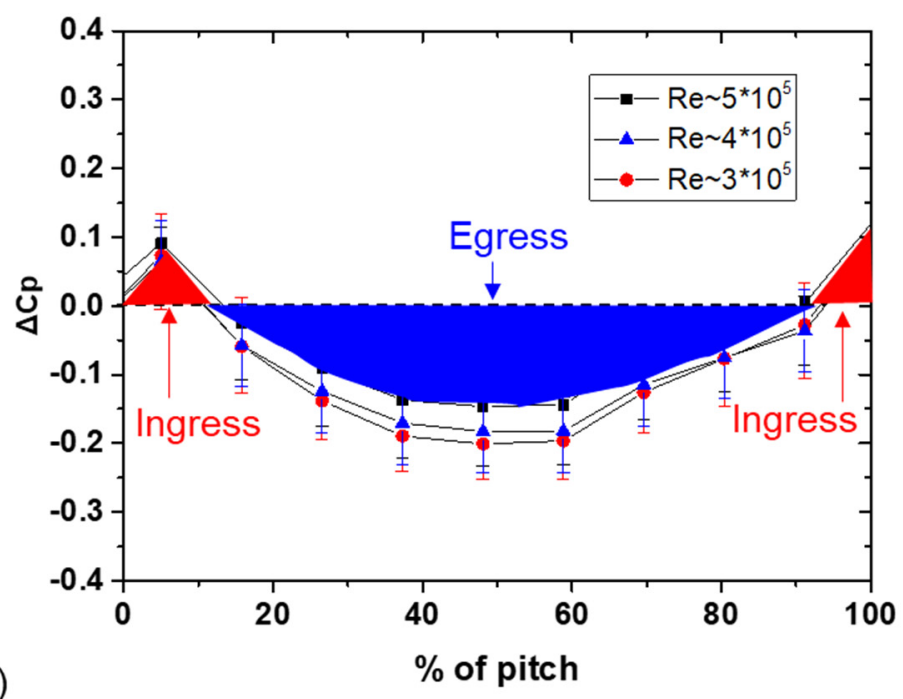

(b)

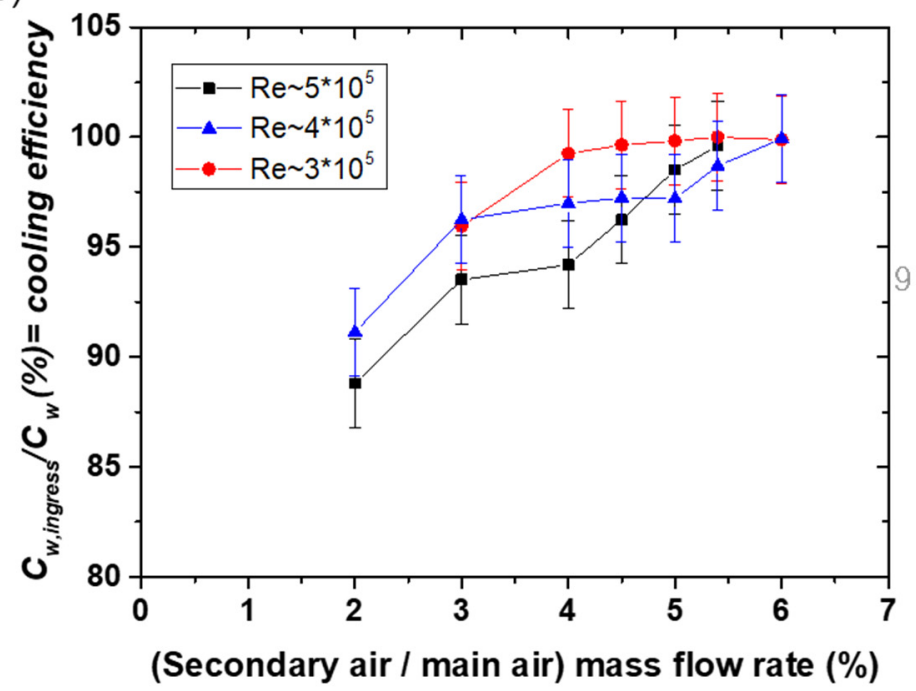

Figure 7. (a) Pressure difference between endwall and rim seal; (b) Ingress and egress ratio of different coolant mass flow rate and rotational speed. 
Figure 8 showed the ratio of the egress flow rate to the total coolant flow of the rim seal according to the change of the cooling flow rate of the main flow. The linear correlation was derived and followed as

$$
C_{w, \text { egress }} / C_{w}=(24.6) \times C_{w} / R e_{\phi}+1.39
$$

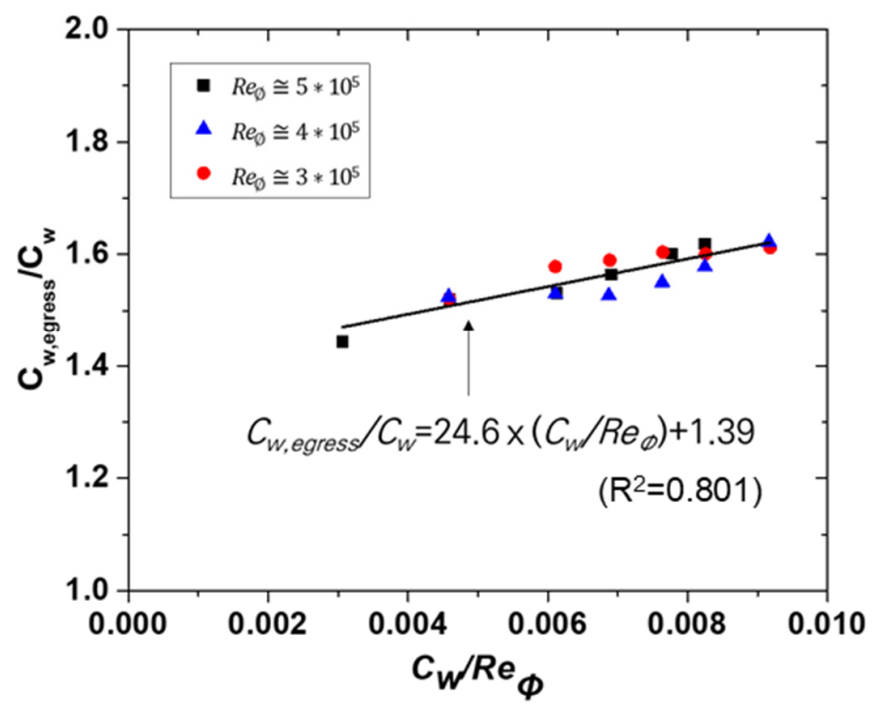

Figure 8. Ingress/egress ratio for coolant mass flow rate at different rotational speeds.

The above equation is a linear equation that can be applied to various rotating Reynolds numbers. Therefore, a linear equation for predicting the sealing effectiveness of the rim seal was derived from the gas turbine rim seal with the flow characteristics as shown in Figure 1. In general, local sealing effectiveness measurements using carbon dioxide concentration measurements are more accurate, but it is considered to be a useful correlation at the gas turbine preliminary design stage by using only the data of pressure distributions. In these circumstances, the above experimental results are considered to be useful when predicting the coolant mass flow rate and sealing effectiveness of the rim seal for the gas turbine cooling designers. However, this experimental data was presented as a basic data of our gas turbine rim seal facility. In the near future, the further experiments will be conducted to find out the appropriate shape of rim seal for our aero-gas turbine.

\section{Conclusions}

An experimental study was conducted to analyze the sealing effectiveness of gas turbine blade rim seal. Experimental facility was designed and fabricated to analyze the sealing effectiveness of the rim seal. Pressure distributions and carbon dioxide concentration were measured at the local points of the shroud, endwall, and rim seal. Experiments were conducted with varying rotational Reynolds numbers and coolant flow rates of the rim seal. Experimental results showed that the ingress effect of the main flow hardly occurred when the coolant mass flow rate of the rim seal was $1.35 \%$ of the main flow, but the ingress effect occurred in some areas when the coolant mass flow rate decreased. In particular, the ingress effect occurred near the trailing edge of the vane, and the sealing effectiveness tended to decrease significantly. Based on the experimental results, the linear equation for predicting the sealing effectiveness of the rim seal according to the rotational Reynolds number was derived. The correlation was derived based on the pressure measurement results, which can be useful for the preliminary design of gas stage and helpful for the turbine cooling designers.

Author Contributions: S.M.C. and S.C. designed and conducted experiments. H.H.C. contributed to analysis and guided writing the manuscript. All authors analyzed the data. All authors discussed the results and commented on the manuscript. All authors have read and agreed to the published version of the manuscript. 
Funding: This work was supported by the Human Resources Development program (No.20204030200110) of the Korea Institute of Energy Technology Evaluation and Planning (KETEP) grant funded by the Korea government Ministry of Trade, Industry, and Energy. This work was supported by the UAV High Efficiency Turbine Research Center program of Defense Acquisition Program Administration and Agency for Defense Development and also partially supported by the Hanwha Aerospace.

Conflicts of Interest: The authors declare no conflict of interest.

\section{Nomenclature}

$\mathrm{C}_{\mathrm{ax}, \mathrm{v}}$

$\mathrm{C}_{\mathrm{ax}, \mathrm{b}}$

$\mathrm{C}_{\mathrm{p}}$

$\mathrm{C}_{\mathrm{w}}$

$\mathrm{c}_{\mathrm{a}}$

$c_{0}$

$\mathrm{c}_{\mathrm{i}}$

$\mathrm{d}_{\mathrm{p}} / \mathrm{C}_{\mathrm{ax}}$

G

$\mathrm{G}_{\text {overlap }}$

L

$\dot{\mathrm{m}}$

$\mathrm{P}_{\mathrm{t}}$

$\mathrm{P}_{\mathrm{s}, \mathrm{i}}$

$\mathrm{P} / \mathrm{C}_{\mathrm{ax}, \mathrm{v}}$

$\mathrm{P} / \mathrm{C}_{\mathrm{ax}, \mathrm{b}}$

$\mathrm{Re}$

$\operatorname{Re}_{\phi}$

$S$

$S_{V}$

$\mathrm{S}_{\mathrm{b}}$

V

U

$\mathrm{x}$

$r$

$\theta$

$\alpha_{1}$

$\alpha_{2}$

$\alpha$

$\rho$

$\varphi$

$\Omega$

$\mu$

$\eta$

turbine blade hub radius of turbine blade (m)

vane axial chord length $(\mathrm{m})$

blade axial chord length $(\mathrm{m})$

pressure coefficient

non-dimensional secondary mass flowrate $\left(\mathrm{C}_{\mathrm{W}}=\frac{\dot{\mathrm{m}}}{\mu \mathrm{b}}\right)$

$\mathrm{CO}_{2}$ concentration of ambient air

$\mathrm{CO}_{2}$ concentration at $\mathrm{r} / \mathrm{R}=0.7$

local $\mathrm{CO}_{2}$ concentration

distance from the vane trailing edge to measurement taps

gap between rim seal of vane and blade $(\mathrm{m})$

rim seal overlap length of the rim seal (m)

length of the glass cylinder (m)

mass flow rate $\left(\mathrm{kg} \mathrm{s}^{-1}\right)$

total pressure at inlet $\left(\mathrm{kg} \mathrm{m}^{-1} \mathrm{~s}^{-2}\right)$

local static pressure $\left(\mathrm{kg} \mathrm{m}^{-1} \mathrm{~s}^{-2}\right)$

vane pitch (nondimensional)

blade pitch (nondimensional)

Reynolds number $\left(\operatorname{Re}=\frac{\rho v C_{\mathrm{ax}, \mathrm{v}}}{\mu}\right)$

Rotational Reynolds number $\left(\operatorname{Re}_{\phi}=\frac{\rho \Omega b^{2}}{\mu}\right)$

blade span (m)

vane rim seal thickness (m)

blade rim seal thickness (m)

velocity of main air flow $\left(\mathrm{m} \mathrm{s}^{-1}\right)$

circumferential velocity of turbine blade $\left(\mathrm{m} \mathrm{s}^{-1}\right)$

coordinate in main flow direction

coordinate in radial direction

coordinate in circumferential direction Greek Symbols

blade inlet angle $\left(^{\circ}\right)$

blade exit angle $\left({ }^{\circ}\right)$

turning angle $\left(^{\circ}\right)$

density of air $\left(\mathrm{kg} \mathrm{m}^{-3}\right)$

flow coefficient

rotational speed $\left(\mathrm{s}^{-1}\right)$

dynamic viscosity of air $\left(\mathrm{kg} \mathrm{m}^{-1} \mathrm{~s}^{-1}\right)$

sealing effectiveness

\section{References}

1. Chupp, R.E.; Hendricks, R.C.; Lattime, S.B.; Steinetz, B.M. Sealing in turbomachinery. J. Pro. Power 2006, 22, 313-349. [CrossRef]

2. Bohn, D.; Wolff, $M$. Improved formulation to determine minimum sealing flow $-\mathrm{C}_{\mathrm{W}, \mathrm{min}}-$ for different sealing configurations. In Proceedings of the ASME Turbo Expo 2003, Collocated with the 2003 International Joint Power Generation Conference, Atlanta, GA, USA, 16 June 2003; pp. 1041-1049.

3. Bohn, D.; Rudzinski, B.; Sürken, N.; Gärtner, W. Influence of rim seal geometry on hot gas ingestion into the upstream cavity of an axial turbine stage. In Proceedings of the ASME 1999 International Gas Turbine and Aeroengine Congress and Exhibition, New York, NY, USA, 7 June 1999; pp. 1-10. 
4. Coren, D.D.; Atkins, N.R.; Turner, J.R.; Eastwood, D.E.; Davies, S.; Childs, P.R.N.; Scanlon, T.S. An advanced multi-configuration stator well cooling test facility. In Proceedings of the ASME Turbo Expo 2010: Power for Land, Sea, and Air, Glasgow, UK, 14 June 2010; pp. 1259-1270.

5. Gentilhomme, O.; Hills, N.J.; Turner, A.B.; Chew, J.W. Measurement and analysis of ingestion through a turbine rim seal. ASME J. Turbo. 2003, 125, 505-512. [CrossRef]

6. Sangan, C.M.; Pountney, O.J.; Zhou, K.; Wilson, M.; Michael Owen, J.; Lock, G.D. Experimental Measurements of Ingestion Through Turbine Rim Seals_Part I: Externally Induced Ingress. J. Turbo. 2013, 135, 021012. [CrossRef]

7. Pau, M.; Paniagua, G.; Delhaye, D.; de La Loma, A.; Ginibre, P. Aerothermal impact of stator-rim purge flow and rotor-platform film cooling on a transonic turbine stage. J. Turbo. 2010, 132, 021006. [CrossRef]

8. Bayley, F.J.; Owen, J.M. The fluid dynamics of a shrouded disk system with a radial outflow of coolant. J. Eng. Power 1970, 92, 335-341. [CrossRef]

9. Owen, J.M.; Rogers, R.H. Flow and Heat Transfer in Rotating-Disc Systems, Volume 1: Rotor-Stator Systems; Research Studies Press: Taunton, UK, 1989.

10. Owen, J.M.; Rogers, R.H. Flow and Heat Transfer in Rotating-Disc Systems, Volume 2: Rotating Cavities; Research Studies Press: Taunton, UK, 1995.

11. Owen, J.M. Prediction of Ingestion through Turbine Rim Seals. Part I: Rotationally Induced Ingress. J. Turbo. 2011, 133, 031005. [CrossRef]

12. Owen, J.M. Prediction of Ingestion through Turbine Rim Seals. Part II: Externally Induced and Combined Ingress. J. Turbo. 2011, 133, 031006. [CrossRef]

13. Owen, J.M.; Zhou, K.; Pountney, O.J.; Wilson, M.; Lock, G.D. Prediction of Ingress through Turbine Rim Seals. Part 1: Externally-Induced Ingress. J. Turbo. 2012, 134, 031012. [CrossRef]

14. Owen, J.M.; Pountney, O.J.; Lock, G.D. Prediction of Ingress through Turbine Rim Seals. Part 2: Combined Ingress. J. Turbo. 2012, 134, 031013. [CrossRef]

15. Owen, J.M. Theoretical modelling of hot gas ingestion through turbine rim seals. Pro. Power 2012, 1, 1-11.

16. Zhou, K.; Wood, S.N.; Owen, J.M. Statistical and theoretical models of ingestion through turbine rim seals. J. Turbo. 2013, 135, 021014. [CrossRef]

17. Mear, L.I.; Owen, J.M.; Lock, G.D. Theoretical Model to Determine Effect of Ingress on Turbine Disks. J. Eng. Gas Turbines Power 2016, 138, 3.

18. Johnson, B.V.; Wang, C.Z.; Roy, R.P. A Rim Seal Orifice Model with 2 Cds and Effects of Swirl in Seals. In Proceedings of the ASME Turbo Expo 2008: Power for Land, Sea, and Air, Berlin, Germany, 9 June 2008; pp. 1531-1547.

19. Zhang, Z.; Ma, H. Application of Phase-Locked PIV Technique to the Measurements of Flow Field in a Turbine Stage. J. Therm. Sci. 2020, 29, 1-9. [CrossRef]

20. Cao, C.; Chew, J.W.; Millington, P.R.; Hogg, S.I. Interaction of rim seal and annulus flows in an axial flow turbine. J. Eng. Gas Turbines Power 2004, 126, 786-793. [CrossRef]

21. Hills, N.J.; Chew, J.W.; Turner, A.B. Computational and mathematical modeling of turbine rim seal ingestion. J. Turbo. 2020, 124, 306-315. [CrossRef]

22. Teuber, R.; Li, Y.S.; Maltson, J.; Wilson, M.; Lock, G.D.; Owen, J.M. Computational extrapolation of turbine sealing effectiveness from test rig to engine conditions. In Proceedings of the ASME Turbo Expo 2012: Turbine Technical Conference and Exposition, Berlin, Germany, 9 June 2012; pp. 167-178.

23. Ding, Z.; Palafox, P.; Moore, K.; Chupp, R.; Kirtley, K. A New 1.5-Stage Turbine Wheelspace Hot Gas Ingestion Rig (HGIR): Part II-CFD Modeling and Validation. In Proceedings of the ASME Turbo Expo 2013: Turbine Technical Conference and Exposition, San Antonio, TX, USA, 3 June 2013; pp. 1-8.

24. Tucker, P.G. Computation of unsteady turbomachinery flows: Part 2-LES and hybrids. Prog. Aerosp. Sci. 2011, 47, 546-569. [CrossRef]

25. Chilla, M.; Hodson, H.; Newman, D. Unsteady interaction between annulus and turbine rim seal flows. J. Turbo. 2013, 135, 051024. [CrossRef]

26. Rabs, M.; Benra, F.K.; Dohmen, H.J.; Schneider, O. Investigation of flow instabilities near the rim cavity of a 1.5 stage gas turbine. In Proceedings of the ASME Turbo Expo 2009: Power for Land, Sea, and Air, Orlando, FL, USA, 8 June 2009; pp. 1263-1272. 
27. Wu, H.; Li, P.; Li, Y. Simulation of unsteady state performance of a secondary air system by the 1D-3D-Structure coupled method. J. Therm. Sci. 2016, 25, 68-77. [CrossRef]

28. Gao, J.; Du, Q.; Liu, J.; Liu, G.; Wang, P.; Liu, H.; Du, M. Flow development through HP \& LP turbines, Part I: Inward rotating cavity flow with superimposed throughflow. J. Therm. Sci. 2017, 26, 297-307.

29. Hu, J.; Du, Q.; Liu, J.; Wang, P.; Liu, G.; Liu, H.; Du, M. Flow development through HP \& LP turbines, Part II: Effects of the hub endwall secondary sealing air flow on the turbine's mainstream flow. J. Therm. Sci. 2017, 26, 308-315.

30. Sangan, C.M.; Pountney, O.J.; Scobie, J.A.; Wilson, M.; Owen, J.M.; Lock, G.D. Experimental Measurements of Ingestion Through Turbine Rim Seals_Part III: Single and Double Seals. J. Turbo. 2013, 135, 051011. [CrossRef]

31. Zhou, D.W.; Roy, R.P.; Wang, C.Z.; Glahn, J.A. Main gas ingestion in a turbine stage for three rim cavity configurations. J. Turbo. 2011, 133, 031023. [CrossRef]

32. Schuler, P.; Kurz, W.; Dullenkopf, K.; Bauer, H.J. The influence of different rim seal geometries on hot-gas ingestion and total pressure loss in a low-pressure turbine. In Proceedings of the ASME Turbo Expo 2010: Power for Land, Sea, and Air, Glasgow, UK, 14 June 2010; pp. 1123-1134.

33. Scobie, J.A.; Teuber, R.; Li, Y.S.; Sangan, C.M.; Wilson, M.; Lock, G.D. Design of an improved turbine rim-seal. J. Eng. Gas Turbines Power 2016, 138, 022503. [CrossRef]

34. Barringer, M.; Coward, A.; Clark, K.; Thole, K.A.; Schmitz, J.; Wagner, J.; Dennis, R. The Design of a Steady Aero Thermal Research Turbine (START) for Studying Secondary Flow Leakages and Airfoil Heat Transfer. In Proceedings of the ASME Turbo Expo 2014: Turbine Technical Conference and Exposition, Dusseldorf, Germany, 16 June 2014. V05CT16A013.

35. Green, T.; Turner, A.B. Ingestion into the upstream wheelspace of an axial turbine stage. In Proceedings of the ASME 1992 International Gas Turbine and Aeroengine Congress and Exposition, Colonge, Germany, 1 June 1992; pp. 1-7.

36. Roy, R.P.; Feng, J.; Narzary, D.; Paolillo, R.E. Experiment on gas ingestion through axial-flow turbine rim seals. J. Eng. Gas Turbines Power 2005, 127, 573-582. [CrossRef]

37. Eastwood, D.; Coren, D.D.; Long, C.A.; Atkins, N.R.; Childs, P.R.N.; Scanlon, T.J.; Guijarro-Valencia, A. Experimental investigation of turbine stator well rim seal, re-ingestion and interstage seal flows using gas concentration techniques and displacement measurements. J. Eng. Gas Turbines Power 2012, 134, 082501. [CrossRef]

38. Regina, K.; Kalfas, A.I.; Abhari, R.S. Experimental Investigation of Purge Flow Effects on a High Pressure Turbine Stage. J. Turbo. 2015, 137, 041006. [CrossRef]

39. Wang, R.; Du, Q.; Liu, G.; Lian, Z.; Xie, L.; Zhu, J. Influence of Secondary Sealing Flow on Performance of Turbine Axial Rim Seals. J. Therm. Sci. 2020, 29, 840-851. [CrossRef]

40. Balasubramanian, J.; Michael, M.; Roy, R.P.; Kim, Y.W.; Moon, H.K. Experiments on front-and aft-disk cavity ingestion in a subscale 1.5-stage axial turbine. In Proceedings of the Turbo Expo: Power for Land, Sea, and Air, Seoul, South Korea, 13 June 2016; pp. 1-16.

41. James, A.S. An Experimental Study of Gas Turbine Rim Seals. Ph.D. Thesis, University of Bath, Bath, UK, 26 June 2014.

42. Pedersen, D.R. Effect of Density Ratio on Film Cooling Effectiveness for Injection through a Row of Holes and for a Porous Slot. Ph.D. Thesis, University of Minnesota, Minneapolis, MN, USA, 9 September 1972.

43. Abernethy, R.B. ASME measurement uncertainty. J. Fluids Eng. 1985, 107, 161-164. [CrossRef]

(C) 2020 by the authors. Licensee MDPI, Basel, Switzerland. This article is an open access article distributed under the terms and conditions of the Creative Commons Attribution (CC BY) license (http://creativecommons.org/licenses/by/4.0/). 